Pesq. Vet. Bras. 36(2):73-76, fevereiro 2016 DOI: $10.1590 / \mathrm{S} 0100-736 \mathrm{X} 2016000200002$

\title{
Prevalence study of SNP c.421G $>T$ in the ADAMTS2 gene responsible for dermatosparaxis in White Dorper sheep in Brazil ${ }^{1}$
}

\author{
Danilo G.A. Andrade ${ }^{2}$, Felipe M. Dalanezi ${ }^{2}$, Anelize S. Trecenti ${ }^{2}$, Paulo Henrique J. \\ Cunha $^{3}$, Alexandre S. Borges ${ }^{2}$ and José P. Oliveira-Filho ${ }^{2 *}$
}

\begin{abstract}
Andrade D.G.A., Dalanezi F.M, Trecenti A.S., Cunha P.H.J., Borges A.S. \& OliveiraFilho J.P. 2016. Prevalence study of SNP c.421G $>$ T in the ADAMTS2 gene responsible for dermatosparaxis in White Dorper sheep in Brazil. Pesquisa Veterinária Brasileira 36(2):73-76. Departamento de Clínica Veterinária, Faculdade de Medicina Veterinária e Zootecnia, Universidade Estadual Paulista "Júlio de Mesquita Filho", Campus de Botucatu, Distrito de Rubião Junior s/n, Botucatu, SP 18618-970, Brazil. E-mail: zefilho@fmvz.unesp.br

Dermatosparaxis is an autosomal recessive disorder of connective tissue; the disorder is clinically characterized by skin fragility and hyperextensibility. Dermatosparaxis in White Dorper sheep is caused by a single nucleotide polymorphism (SNP) (c.421G>T) in the ADAM metalloproteinase with thrombospondin type 1 motif, 2 (ADAMTS2) gene. The aim of this study was to investigate the prevalence of this SNP in a White Dorper herd in São Paulo state, Brazil. In this study, we collected blood DNA samples from 303 White Dorper sheep and performed polymerase chain reaction to amplify the SNP region. The samples were sequenced to determine the presence of the SNP in the ADAMTS2 gene. The SNP prevalence in the studied population was $15.5 \%$; this finding indicates that more effective control measures should be used to prevent the inheritance of SNP c.421G $>$ T in the ADAMTS2 gene in Brazilian White Dorper herds.
\end{abstract}

INDEX TERMS: Cutaneous asthenia, autosomal recessive, PCR, White Dorper, sheep.

RESUMO.- [Prevalência do SNP c.421G >T no gene ADAMTS2 responsável pela dermatosparaxia em ovinos White Dorper no Brasil.] A dermatosparaxia é uma doença autossômica recessiva do tecido conjuntivo, clinicamente caracaterizada pela fragilidade e hiperextensibilidade da pele. A dermatosparaxia em ovinos White Dorper é causada pelo polimorfismo de base única (SNP) c.421G $>$ T no gene ADAM metalopeptidase com trombospondina tipo 1 motif, 2 (ADAMTS2). 0 objetivo deste estudo foi investigar a prevalência deste SNP em ovinos White Dorper no estado de São Paulo, Brasil. Foram coletadas amostras de sangue de 303 ovinos White Dorper. O DNA foi purificado

\footnotetext{
${ }^{1}$ Received on September 24, 2015.

Accepted for publication on January 15, 2016.

${ }^{2}$ Departamento de Clínicas Veterinárias, Faculdade de Medicina Veterinária e Zootecnia, Universidade Estadual Paulista (Unesp), Campus de Botucatu, Distrito de Rubião Júnior s/n, Botucatu, SP 18618-000, Brazil. *Corresponding author: zefilho@fmvz.unesp.br

${ }^{3}$ Departamento de Medicina Veterinária, Escola de Veterinária, Universidade Federal de Goiás (UFG), Campus Samambaia (Campus II), Cx. Postal 131, Goiânia, GO 74001-970, Brazil.
}

destas amostras sanguíneas e utilizado em uma reação em cadeia da polimerase (PCR) para amplificação da região do gene contendo SNP c.421G>T. Os produtos das PCR foram sequenciados para determinar o genótipo dos animais. A prevalência do SNP na população estudada foi de 15,5\%, estes achados indicam que medidas de controle efetivas devem ser utilizadas para prevenir a disseminação deste SNP no rebanho brasileiro de White Dorper.

TERMOS DE INDEXAÇÃO: Astenia cutânea, autossômica recessiva, PCR, White Dorper, ovinos.

\section{INTRODUCTION}

Dermatosparaxis, also known as cutaneous asthenia or cutis hyperelastica, is a heritable autosomal recessive collagen dysplasia (Scott 2007). Its clinical signs include loose, hyperextensible, and fragile skin that is easily torn by minor trauma (Fig.1) (Andrade et al. 2014). These skin defects prevent affected animals from entering the breeding system because they are either discarded or removed from their usual activities due to wound infections and septicemia (Fjølstad \& Helle 1974). In humans, dermatosparaxis 


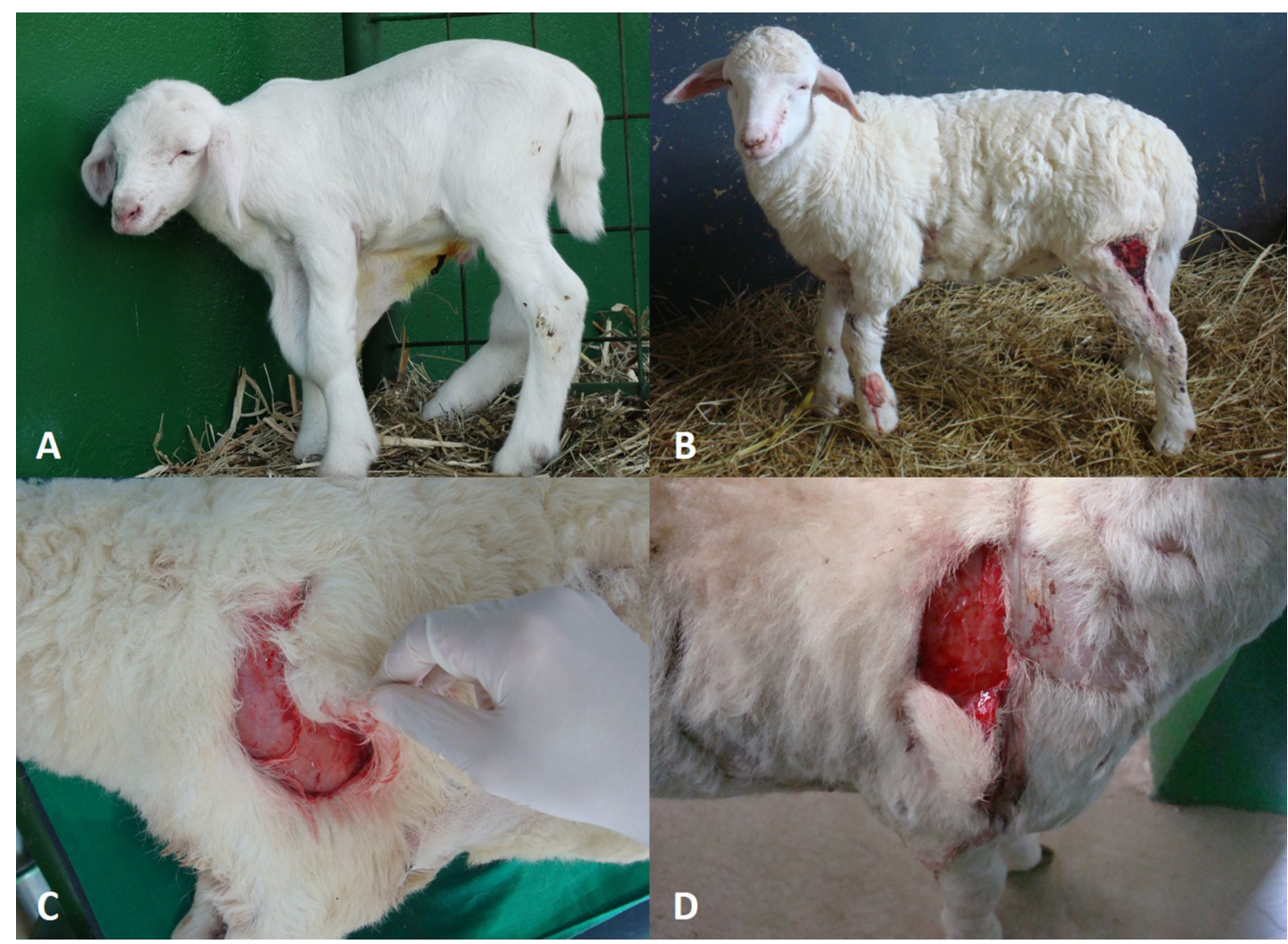

Fig.1. Two White Dorper lamb with dermatosparaxis, showing (A) skin hyperextensibility in the chest area and (B) skin wound. (C,D) Skin wound and flap in affected lambs.

is part of a large spectrum of connective tissue disorders known as Ehlers-Danlos syndrome (EDS) and is classified as EDS type VIIC (Colige et al. 1999). Dermatosparaxis has previously been described in many species, including cattle (Kawaguchi et al. 1988), horses (White et al. 2004), dogs (Paciello et al. 2003), cats (Sequeira et al. 1999), and rabbits (Sinke et al. 1997). The disorder occurs predominately in White Dorper sheep and has been reported in South Africa (van Halderen \& Green 1988), Australia (Aggs 2007), Spain (Sucupira et al. 2009), New Zealand (Vaatstra et al. 2011), the United States (Grant and Patton 2012) and Brazil (Andrade et al. 2014, Silva et al. 2015). However, other breeds may also be affected (Fjølstad \& Helle 1974, Ramshaw et al. 1983, Van Weeren-Keverling \& Koeman 1986, Monteagudo et al. 2015).

Dermatosparaxis in White Dorper sheep is caused by a single nucleotide polymorphism (SNP) in the ADAMTS2 gene (Zhou et al. 2012), which is similar to the gene found in both humans and cattle (Colige et al. 1999). This SNP results in deficient type I procollagen due to a defect in the $\mathrm{N}$-terminal portion of the protein (Lapière et al. 1971). The mutant protein assembles into abnormal collagen fibrils that do not facilitate the development of normal skin (Zhou et al. 2012). There is currently no treatment for this disease. Thus, the identification of SNP c.421G $>\mathrm{T}$ in exon 2 of the ADAMTS2 gene prior to breeding could help control dermatosparaxis in White Dorper sheep. Heterozygous animals are phenotypically normal. Therefore, it is important to minimize the number of affected animals, thereby reducing economic losses. The aim of this study was to in- vestigate the prevalence of the above-mentioned SNP in a White Dorper herd located in Sao Paulo state, Brazil.

\section{MATERIALS AND METHODS}

The sample size was calculated using OpenEpi software (online version 3.0.1.) by applying a $5 \%$ error margin and using a population of 9,772 registered White Dorper sheep (Brazilian Association of Sheep Breeders - ARCO - Associação Brasileira de Criadores de Ovinos) with a confidence interval of $95 \%$. The result was a sample size of 253 animals. There have been no previous studies examining the SNP prevalence in Brazil. Therefore, the prevalence of heterozygous animals in the unaffected sheep population was estimated to be $21.5 \%$ based on a previous study from New Zealand (Zhou et al. 2012). The prevalences of heterozygous animals in our study and the study by Zhou et al. (2012) were compared using a chi-square test. All statistical tests were performed using GraphPad Prism ${ }^{\circledR}$ version 5.01 for Windows (GraphPad Software).

Genomic DNA was extracted from blood samples with the GenElute $^{\mathrm{TM}}$ Genomic Blood DNA Kit (Sigma-Aldrich ${ }^{\circledR}$ ) according to the manufacturer's instructions. PCR was performed using specific primers that amplify a 231-bp fragment containing the c. $421 \mathrm{G}>\mathrm{T}$ mutation in the ADAMTS2 gene based on a previously described method (Andrade et al. 2014). The PCR products were analyzed by $1.5 \%$ agarose gel electrophoresis. The products with the correct size were purified using the GenElute ${ }^{\mathrm{TM}}$ PCR Clean-Up Kit (Sigma-Aldrich ${ }^{\circledR}$ ). To sequence the DNA, we used $10 \mu \mathrm{L}$ of each PCR product, $5 \mu \mathrm{L}$ of the purified reverse primer and the BigDye ${ }^{\circledR}$ Terminator Cycle Sequencing Kit (Life Technologies ${ }^{\mathrm{TM}}$, CA, USA). The sequences were determined using the ABI 3500 Genetic Analyzer (Life Technologies ${ }^{\mathrm{TM}}$ CA, USA). The obtained sequences and the electropherograms were analyzed using Sequencher ${ }^{\mathrm{TM}} 5.1$ (Gene Codes, MI, USA). The sequences were compared with the 
normal sheep ADAMTS2 gene sequence (GenBank ${ }^{\mathrm{TM}}$ JF357978.1) using BLAST (Basic Local Alignment Search Tool, http://blast. ncbi.nlm.nih.gov/Blast.cgi).

\section{RESULTS AND DISCUSSION}

DNA from blood samples was obtained from 303 White Dorper sheep. There were 230 (75.9\%) females and 73 (24.1\%) males in the population, which was registered at the Brazilian Association of Sheep Breeders (ARCO). The samples were obtained from 12 farms in different regions of Sao Paulo state (Fig.2). This state was chosen because it belongs to the Brazilian zone that had the greatest increase $(86.1 \%)$ in the sheep population between 2,000 and 2,012 (Raineri et al. 2014). Additionally, Sao Paulo has the largest White Dorper sheep population in the Brazilian states (ARCO) and has farms that sell their animals throughout the country.

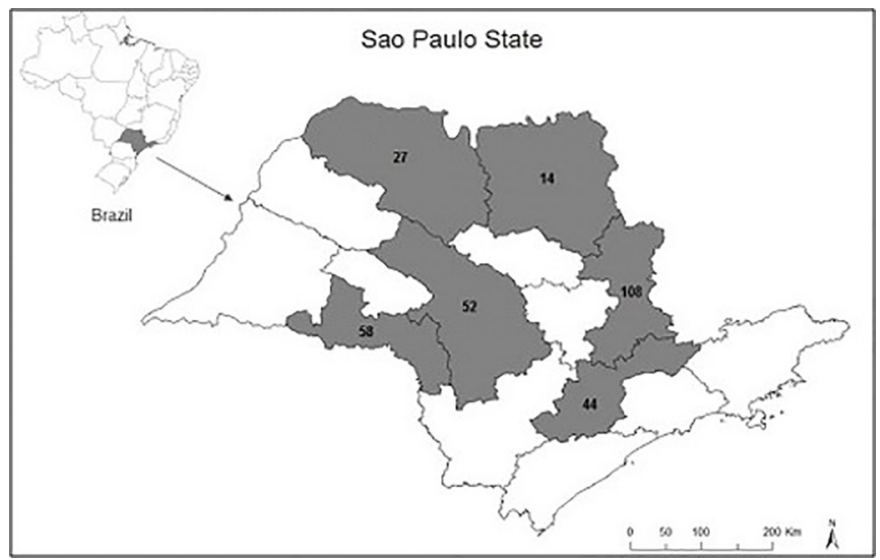

Fig.2. Number of sampled animals by region of Sao Paulo state, Brazil. Adapted from <http://www.mapasparacolorir.com.br/>

Heterozygous animals were identified in 83\% (10/12) of the sampled farms (Table 1). However, no animals with clinical signs of dermatosparaxis were identified during the technical visits. However, the owners indicated that there were clinical examples in $25 \%$ (3/12) of the sampled farms. The breeders had no knowledge regarding the cause of the animals' disease.

A total of $256(84.5 \%)$ animals had no alleles containing the SNP c.421G>T in exon 2 of the ADAMTS2 gene (Wild Type, N/N). Forty-seven (15.5\%) animals had only one affected allele (heterozygotes, A/N). The frequency of $\mathrm{A} / \mathrm{N}$ animals (15.5\%) was not significantly different than

Table 1. Percentage of animal genotypes by farm

\begin{tabular}{lccc}
\hline & Wild types $(\mathrm{N} / \mathrm{N})$ & Heterozygotes $(\mathrm{A} / \mathrm{N})$ & Sampling \\
\hline Farm A & $78.1 \%$ & $21.9 \%$ & 32 \\
Farm B & $78.6 \%$ & $21.4 \%$ & 14 \\
Farm C & $81.3 \%$ & $18.7 \%$ & 16 \\
Farm D & $100.0 \%$ & $0.0 \%$ & 23 \\
Farm E & $92.6 \%$ & $7.4 \%$ & 27 \\
Farm F & $81.8 \%$ & $18.2 \%$ & 44 \\
Farm G & $77.8 \%$ & $22.2 \%$ & 27 \\
Farm H & $61.5 \%$ & $38.5 \%$ & 13 \\
Farm I & $73.1 \%$ & $26.9 \%$ & 26 \\
Farm J & $90.0 \%$ & $10.0 \%$ & 40 \\
Farm K & $88.9 \%$ & $11.1 \%$ & 18 \\
Farm L & $100.0 \%$ & $0.0 \%$ & 23
\end{tabular}

the frequency observed in a New Zealand study with White Dorper sheep from 10 farms $(21.5 \%$; 48/223) $(\mathrm{P}=0.0765)$ (Zhou et al. 2012).

According to the study by Kelly (2012), approximately $15.3 \%$ of the samples submitted to the genetics laboratory at Elizabeth MacArthur Agricultural Institute (EMAI) in Australia had the SNP. The samples were from New Zealand, South Africa, and Australia. However, the reason for testing is unknown; therefore, this frequency may not represent the allele frequency in the White Dorper population.

A missense SNP was recently identified in homozygosis (recessive autosomal inheritance) in the fourth exon of the ADAMTS2 gene. This SNP was the cause of dermatosparaxis in an affected lamb of a crossbreed ovine flock (Monteagudo et al. 2015). We did not test any SNPs in exon 4 of the ADAMTS2 gene because the aim of our study was to investigate the SNP c.421G>T in exon 2.

Similar to dermatosparaxis, most of the genetic diseases that affect sheep are also autosomal recessive (Basrur \& Yadav 1990). Therefore, adopting control measures to identify heterozygous animals is important because these measures will minimize significant economic losses and casualties of affected animals resulting from breeding phenotypically normal heterozygous animals that can produce affected lambs.

Genetic diseases affecting ruminants are relatively common and can be economically important in certain breeds. However, these genetic diseases can be controlled in a cost effective manner (Jolly 2002). The implementation of control programs for genetic diseases in animals is complex because the programs depend on investments in research as well as the cooperation between breeders, researchers, and institutions. These programs produce a superior response when breeding associations are involved due to their management of animal records. We hope that with this study will lead to the development of a control program for dermatosparaxis in Brazilian White Dorper herds.

These findings led us to conclude that dermatosparaxis is highly prevalent in White Dorper sheep herds in Sao Paulo state, Brazil.

Acknowledgements.- The authors acknowledge the funding agency CAPES (Coordenação de Aperfeiçoamento de Pessoal de Nível Superior) for its financial support (AUX-PE-PREMIO - 432/2014) and for awarding a scholarship to Danilo G. A. de Andrade. In addition, we also thank all the farmers who provided their animals, and ARCO (Associação Brasileira de Criadores de Ovinos).

Conflict of interest.- The authors declare no conflicts of interest.

\section{REFERENCES}

Aggs R. 2007. Screen test for fragile skin. Agriculture Today. Available at <http://www.dpi.nsw.gov.au/archive/agriculture-today-stories/ ag-today-archives/august-2007/fragile-skin> Accessed on July 17, 2015.

Andrade D.G.A., Pavan L.F., Amorim R.M., Chiacchio S.B., Laufer-Amorim R., Gonçalves R.C., Borges A.S. \& Oliveira-Filho J.P. 2014. Aspectos clínicos, histopatológicos e moleculares da dermatosparaxia em ovinos White Dorper. Pesq. Vet. Bras. 34:442-448.

Basrur P.K. \& Yadav B.R. 1990. Genetic diseases of sheep and goats. Vet. Clin. North Am., Food Anim. Pract. 6:779-802. 
Colige A., Sieron A.L., Li S.W., Schwarze U., Petty E., Wertelecki W., Wilcox W., Krakow D., Cohn D.H., Reardon W., Byers P.H., Lapière C.M., Prockop D.J. \& Nusgens B.V. 1999. Human Ehlers-Danlos syndrome type VII C and bovine dermatosparaxis are caused by mutations in the procollagen I N-proteinase gene. Am. J. Hum. Genet. 65:308-317.

Fjølstad M. \& Helle 0. 1974. A hereditary dysplasia of collagen tissues in sheep. J. Pathol. 112:183-188.

Grant D. \& Patton W. 2012. Dermatosparaxis in White Dorpers. Available at <http://www.dorper.org/PDF_SALE/DERMATOSPARAXIS.pdf> Accessed on March 3, 2014.

Jolly R.D. 2002. Screening for genetic diseases in cattle. Aust. Vet. J. 80:284285.

Kawaguchi T., Fukazawa H., Naito Y. \& Okada K. 1988. Dermal dysplasia characterized by collagen disorder-related skin fragility in a cow. Am. J. Vet. Res. 49:965-971.

Kelly J. 2012. Dermatosparaxis in a white dorper flock. Flock and Herd. Available at <http://www.flockandherd.net.au/sheep/reader/dermatosparaxis.html> Accessed on July 23, 2015.

Lapière C.M., Lenaers A. \& Kohn L.D. 1971. Procollagen peptidase: an enzyme excising the coordination peptides of procollagen. Proc. Natl Acad. Sci. USA 68:3054-3058.

Monteagudo L.V., Ferrer L.M., Catalan-Insa E., Savva D., McGuffin L.J. \& Tejedor M.T. 2015. In silico identification and three-dimensional modelling of the missense mutation in ADAMTS2 in a sheep flock with dermatosparaxis. Vet. Dermatol. 26:49-e16.

Paciello O., Lamagna F., Lamagna B. \& Papparella S. 2003. Ehlers-DanlosLike Syndrome in 2 Dogs: Clinical, Histologic, and Ultrastructural Findings. Vet. Clin. Pathol. 32:13-18.

Raineri C., Santos F.F. \& Gameiro A.H. 2014. Ovinocultura de corte no Brasil: balanço de 2013 e perspectivas para 2014. Revta Educ. Contin. Med. Vet. Zootec. CRMV-SP 12:12-17.
Ramshaw J.A., Peters D.E., Jones L.N., Badman R.T. \& Brodsky B.B. 1983. Ovine dermatosparaxis. Aust. Vet. J. 60:149-151.

Silva A.P.C., Mol J.P.S., Carvalho Junior C.A., Paixão T.A. \& Santos R.L. 2015. Dermatosparaxis in two White Doper lambs in Brazil: case report. Arq. Bras. Med. Vet. Zootec. 67:741-746.

Scott D.W. 2007. Color Atlas of Farm Animal Dermatology. Blackwell Publishing Professional, Ames.

Sequeira J.L., Rocha N.S., Bandarra E.P., Figueiredo L.M.A. \& Eugenio F.R. 1999. Collagen dysplasia (Cutaneous asthenia) in a cat. Vet. Pathol. 36:603-606.

Sinke J.D., Van Dijk J.E. \& Willemse T. 1997. A case of Ehlers-Danlos-like syndrome in a rabbit with a review of the disease in other species. Vet. Quart. 19:182-185.

Sucupira M.C.A., Arcaute M.R., Lacasta D., Perez M.J., Ramos J.J., Verde M.T. \& Ferrer L.M. 2009. Enfermedades Congénitas y Hereditarias de la Piel de los Cordeiros. I. Albéitar, Espanha, p.36-37.

Vaatstra B.L., Halliday W.D. \& Waropastrakul S. 2011. Dermatosparaxis in two White Dorper lambs. N. Z. Vet. J. 59:258-260.

Van Halderen A. \& Green J.R. 1988. Dermatosparaxis in White Dorper sheep. J. South Afr. Vet. Assoc. 59:45.

Van Weeren-Keverling B.A. \& Koeman J.P. 1986. A form of dermatosparaxis in a Texel lamb. Tijdschr. Diergeneeskd. 111:173-177.

White S.D., Affolter V.K., Bannasch D.L., Schultheiss P.C., Hamar D.W., Chapman P.L., Naydan D., Spier S.J., Rosychuk R.A., Rees C., Veneklasen G.O., Martin A., Bevier D., Jackson H.A., Bettenay S., Matousek J., Campbell K.L. \& Ihrke P.J. 2004. Hereditary equine regional dermal asthenia ("hyperelastosis cutis") in 50 horses: clinical, histological, immunohistological and ultrastructural findings. Vet. Dermatol. 15:207-217.

Zhou H., Hickford J.G. \& Fang Q. 2012. A premature stop codon in the ADAMTS2 gene is likely to be responsible for dermatosparaxis in Dorper sheep. Anim. Genet. 43:471-473. 